\title{
Assessment of Organic Fraction Based on Its Molecular Weight and Disinfection by-Product Formation Through Different Coagulant
}

\author{
Euis Nurul Hidayah"", Okik Hendriyanto Cahyonugroho' \\ 1 Department of Environmental Engineering, University of Pembangunan Nasional Veteran Jawa Timur, \\ Indonesia \\ * Corresponding author's e-mail: euisnh.tl@upnjatim.ac.id
}

\begin{abstract}
Chlorination is the most common disinfection method used in the drinking water production. Reactivity of chlorine with organic molecules could generate disinfection by-product (DBPs), which are harmful to the human health. Natural organic matter (NOM) is a complex mixture of chemicals existing in source water. Because of its complexity, it is conjectured that formation of many different DBPs can arise from the reaction of organic matter and a chemical disinfectant. This study used model compounds as NOM surrogates in order to reveal the specific organic fraction and DBPs formation potential removed by different coagulants. Model compounds, as an artificial sample, were made from a mixture of Suwannee River Humic Acid (SRHA), Suwannee River Fulvic Acid (SRFA), Bovine Serum Albumin (BSA), Alginic Acid (AA). Alum and $\mathrm{FeCl}_{3}$ were used as coagulants. The samples were analyzed for organic parameters, such as total organic carbon (TOC), ultraviolet at $254 \mathrm{~nm}$ wavelength $\left(\mathrm{UV}_{254}\right)$, specific $\mathrm{UV}$ absorbance (SUVA), and organic fractionated by high performance size exclusion chromatograph with organic carbon detector (HPSEC-OCD). The concentration of trihalomethanes (THMs) and haloacetic acids (HAAs) was measured to present the DBPs formation. The results show alum and $\mathrm{FeCl}_{3}$ removed biopolymer (Peak A), humic substances-like (Peak B, Peak C) at the same percentage, while low molecular weight acid and neutral (Peak D) showed a higher removal with alum than $\mathrm{FeCl}_{3}$. HAAs removal led to a greater reduction than THMs removal, and $\mathrm{FeCl}_{3}$ showed a higher removal than the alum coagulant. It indicated that alum and $\mathrm{FeCl}_{3}$ coagulant have different ability in removing specific organic fractions, which are precursors of THMs and HAAs formation.
\end{abstract}

Keywords: model organic compound, fractionation, alum, $\mathrm{FeCl}_{3}$, disinfection by-product

\section{INTRODUCTION}

Disinfection is one of the water treatment processes that are necessary to prevent the spread of waterborne disease. Disinfection has been conducted through many methods, including chemical disinfectant (chlorination), ozonation, and ultraviolet. Chlorination is the most common disinfectant used in drinking water production. It is due to the chlorine properties, such as stability or chlorine existing in the distribution system as well as its reactivity with organic and inorganic present in water (Singer, 2006; Edzwald and Tobiason, 2011). Reactivity of chlorine with organic molecules could generate disinfection by-products (DBPs), which are harmful to the human health. DBPs have been identified as hundreds of species. However, only two groups, namely trihalomethanes (THMs) and haloacetic acids (HAAs), are the most prominent and considered to be DBPs in the treated water (Krasner et al., 2006; Kristiana et al., 2012).

Natural organic matter (NOM) might exist in source water, especially in river water. On the basis of its sources it was identified that organic matter is originated from humic substances in terrestrial watershed (allochthonous) and from biotic activities in water bodies (autochthonous), instead of from wastewater effluent (effluent organic matter). Organic matter is also classified based on its molecular weight, including high molecular weight such as humic-like and aromatic compound, intermediate molecular weight, such as building block compound-like, and low 
molecular weight, such as low molecular acid, neutral and aliphatic organic structure (Leenher and Croue, 2003; Sillanpää et al., 2015). According to the complex properties of organic matter, it can be conjectured that formation of many different DBPs can arise from the reaction of organic matter and chemical disinfectant. Many different conclusions pertaining to DBPs precursors were drawn, for example: the THMs formation was affected by hydrophobic acid organic fraction (Lamsal et al., 2012; Kim and Yu, 2005), aliphatic biopolymer fraction (Hidayah et al. 2016). Meanwhile, the formation of HAAs depended on aromatic hydrophobic compounds (Liang and Singer, 2003), humic substances (Hidayah et al., 2016), hydrophilic fraction (Kim and Yu, 2005).

The DBPs formation could be prevented through removing NOM before the disinfection process. A number of characterizations of organic matter have been developed (Matilainen et al., 2011; Tran et al., 2015; Sillanpää et al., 2015) along with the treatment processes to remove NOM, such as pre-oxidation, coagulation, ion exchange, adsorption, membrane process, and their combinations(Reckhow and Singer, 2011; Lai et al., 2015; Xie et al., 2016). Coagulation is the most common treatment for the removal if organic compounds, even pre-oxidation has been applied as pretreatment to improve coagulation performance (Han et al., 2015; Xie et al., 2016; Hidayah et al., 2017; Hidayah and Yeh, 2018). Principally, treatment process should consider the characteristic of organic compound, because each treatment the process could remove different organic matter properties. Nevertheless, although a number of NOM removal and NOM characterization methods have been developed, organic matters still exist and are poorly characterized (Matilainen et al., 2011; Tran et al., 2015).

In order to know the fate of organic matters changing after treatment and to reveal the formation mechanism of DBPs, model compounds have been applied as NOM surrogates (Liang and Singer, 2003; Bond et al., 2009). Model compounds have well-defined physicochemical properties; therefore, it is commonly used to represent the phenomenon of organic matters in water. The studies related to using model compounds than river water for the simultaneous characterization of organic matters and formation of DBPs are less numerous (Tubic et al., 2013; Wang et al., 2013; Hidayah et al., 2017; Cahyonugroho and Hidayah, 2018). In this study, model compounds were treated by alum or $\mathrm{FeCl}_{3}$ coagulant in order to characterize the specific compound removed by a different coagulant. Organic matter was fractionated by high performance size exclusion chromatography with organic carbon detector (HPSEC-OCD), and those fractionated organics were assessed with the DBPFP concentration. Integration between HPSEC-OCD and DBPs concentration revealed specific organic compounds which are more amenable to removal by a specific coagulant.

\section{MATERIALS AND METHODS}

Two jar batches were filled with $1000 \mathrm{~mL}$ of artificial water sample. The composition of the artificial sample includes Suwannee River Humic Acid (SRHA), Suwannee River Fulvic Acid (SRFA), Bovine Serrum Albumin (BSA), Alginic Acid (AA), as shown in Table 1. Then, various dosages of $0.09 ; 0.19 ; 0.37 ; 0.56(\mathrm{mmol} / \mathrm{L}$ as $\mathrm{Al})$ of $\mathrm{Al}_{2}\left(\mathrm{SO}_{4}\right)_{3} .18 \mathrm{H}_{2} \mathrm{O}$ coagulant and $0.09 ; 0.18$; $0.36 ; 0.54(\mathrm{mmol} / \mathrm{L}$ as $\mathrm{Fe})$ of $\mathrm{FeCl}_{3}$ were added into each set of jar batches. The experiment was conducted under rapid mixing $100 \mathrm{rpm}$ for $3 \mathrm{~min}$, followed by slow mixing $35 \mathrm{rpm}$ for $15 \mathrm{~min}$, then settling for $30 \mathrm{~min}$. The supernatant liquid was collected for the water quality analysis. The sample was filtered through $0.45 \mu \mathrm{m}$ celluloce acetate filter (Advantec, Japan) for further analysis. The characteristics of organic compounds, such as total organic carbon (TOC) were measured by using a TOC analyzer (Model TOC-500, Shimadzu, Kyoto, Japan). Ultraviolet with $254 \mathrm{~nm}\left(\mathrm{UV}_{254}\right)$ was measured using a UV/vis spectrophotometer (Model U-2001, Hitachi, Japan). Specific ultraviolet absorbance (SUVA) value was calculated based on the TOC and UV UV $_{254}$ value (APHA, 2012).

High performance liquid chromatography (HPLC, LC-20 ATV, Shimadzu, Japan)-SEC connected with OCD on-line detectors (modified Sievers TOC Analyzer 900 Turbo, GE Water \& Process Technologies) and a ultraviolet detector (UVD) at $254 \mathrm{~nm}$ (SPD-20A, UV-vis detector, Shimadzu) was used to investigate the composition of dissolved organic matter as a function of apparent molecular weight (MW), as described in Hidayah et al., (2016). Chromatograms were analyzed using Peakfit (Version 4, Systat Software Inc.), a peak fitting technique, to resolve the overlapping peaks (PeakFit, 2003; Lai et al., 2015; Hidayah et al., 2016). The chlorine disinfection 
Table 1. Composition of organic compound for artificial source water

\begin{tabular}{|l|c|c|c|c|}
\hline \multicolumn{1}{|c|}{ Source water } & $\begin{array}{c}\text { SRHA } \\
(\mathrm{mg} / \mathrm{L})\end{array}$ & $\begin{array}{c}\text { SRFA } \\
(\mathrm{mg} / \mathrm{L})\end{array}$ & $\begin{array}{c}\text { BSA } \\
(\mathrm{mg} / \mathrm{L})\end{array}$ & $\begin{array}{c}\text { AA } \\
(\mathrm{mg} / \mathrm{L})\end{array}$ \\
\hline Mixed Organic Compound 1 (MOC-1) & 0.8 & 3.2 & 1.6 & 0.4 \\
\hline Mixed Organic Compound 2 (MOC-2) & 2.4 & 3.2 & 1.6 & 0.4 \\
\hline
\end{tabular}

experiments were conducted in a dark brown glass bottle. Sodium hypochlorite solution was injected to the samples. Then, the samples were placed in the thermostat at $25^{\circ} \mathrm{C}$ for 7 days. After 7 days, the residual chlorine concentration, trihalomethanes, and haloacetic acids concentration were measured in the sample. Trihalomethanes with four species: $\mathrm{CHCl}_{3}, \mathrm{CHBrCl}_{2}, \mathrm{CHBr}_{2} \mathrm{Cl}, \mathrm{CHBr}_{3}$, are known as trihalomethanes formation potential (THMFP) and haloacetic acids with nine species: $\mathrm{CH}_{2} \mathrm{ClCOOH}, \mathrm{CH}_{2} \mathrm{BrCOOH}, \mathrm{CHCl}_{2} \mathrm{COOH}$, $\mathrm{CHBrClCOOH}, \mathrm{CHBr}_{2} \mathrm{COOH}, \mathrm{CCl}_{3} \mathrm{COOH}$, is known as the haloacetic acids formation potential (HAAFP). THMFP and HAAFP were measured according to Hidayah et al., (2017).

\section{RESULTS AND DISCUSSION}

\section{Characteristics of raw sample}

Figure 1 shows the HPSEC-OCD and UVD chromatograms, which are overlapped. The results indicate that Peak A appears in HPSECOCD and vice versa in UVD chromatograms, while the remaining peak shows in both detectors. It explains that Peak A in sample is might be indicated by polysaccharide or amino sugars, as well as Peak A in artificial source water is contributed by BSA and AA. Those compounds lack detection by UVD, as UVD can detect only constituent absorb ultraviolet light, such as aromatic or conjugated double bond organic carbon, while OCD can detect all organic containing carbon. Peak B (humic substances), Peak C (building blocks), and Peak D (low molecular weight acids and humics) represented the other humic substances, like organic compounds.

The peak area of the HPSEC-OCD chromatogram, which was resolved by PeakFit, and percentage distribution of each peak in sample is shown in Table 2. First, artificial source water shows the total area of MOC-2 is larger than that of MOC-1. This is consistent with the higher TOC value of MOC-2 than that of MOC-1. Second, the sum percentage of Peak B, C and D in sample is much larger (about $62 \%-66 \%$ ) than that of Peak A (about 34\%-38\%).

This means that NOM in the sample contains a greater amount of the hydrophobic organic fraction, which is consistent with the high SUVA value, as shown in Table 3. The SUVA value is one of the NOM surrogate parameters, which indicated hydrophobicity or hydrophilicity of NOM properties. The NOM surrogate parameters pertaining to the water quality of these artificial waters is shown in Table 3. It is noted that the those artificial water have comparable $\mathrm{pH}$ values.
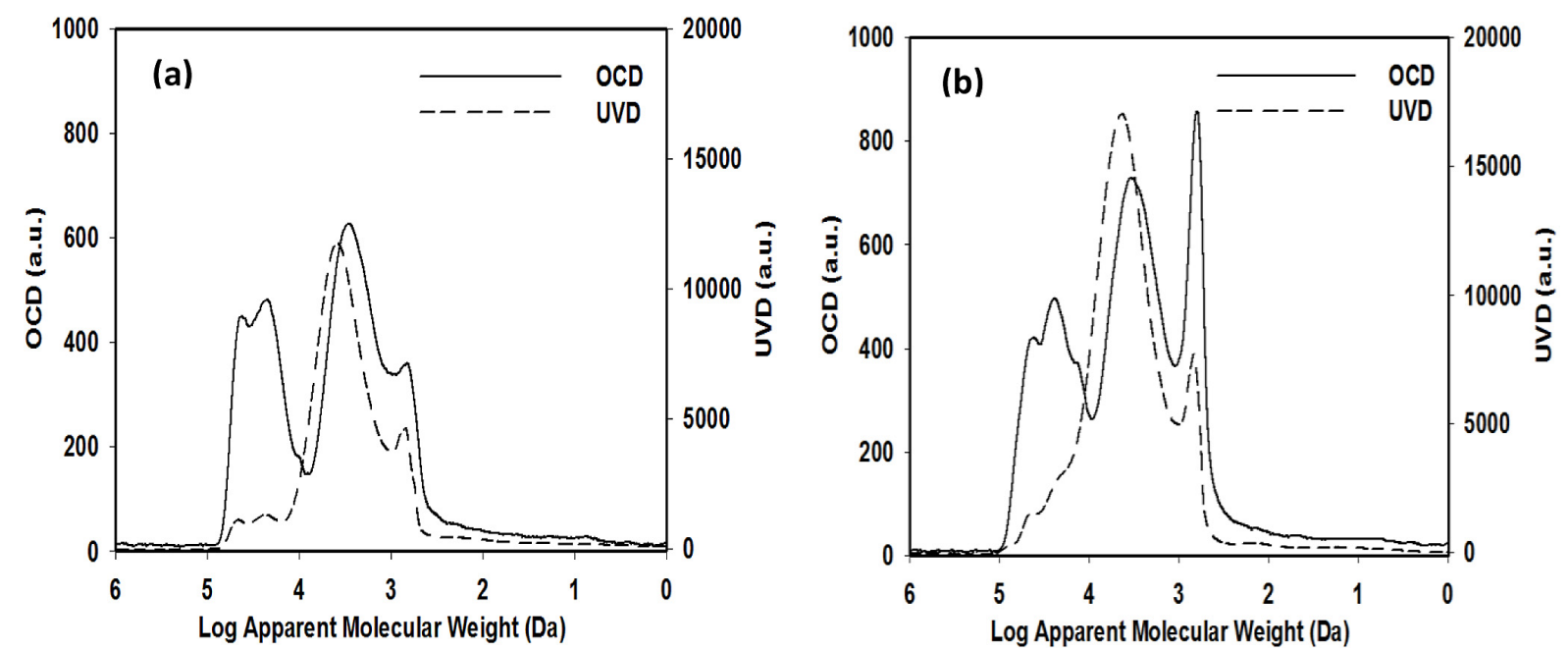

Fig. 1. Characteristic of organic fractions by HPSEC-OCD and HPSEC-UVD in (a) MOC-1, and (b) MOC-2 
Table 2. The peak area and percentage distribution of the HPSEC-OCD chromatograms of sample water with peak-fitting

\begin{tabular}{|c|c|c|}
\hline \multirow{2}{*}{ Organic fractions } & \multicolumn{2}{|c|}{ Area (a.u.) } \\
\cline { 2 - 3 } & MOC-1 & MOC-2 \\
\hline Peak A & $299.7\left(38.2^{*}\right)$ & $389.6\left(34.2^{*}\right)$ \\
\hline Peak B & $376.0\left(47.9^{*}\right)$ & $41.8\left(47.8^{*}\right)$ \\
\hline Peak C & $37.5\left(4.8^{*}\right)$ & $163.6\left(14.4^{*}\right)$ \\
\hline Peak D & $72.0\left(9.2^{*}\right)$ & $1139.7\left(100^{*}\right)$ \\
\hline Total & $785.2\left(100^{*}\right)$ & \\
\hline
\end{tabular}

"percentage distribution (\%).

Table 3. Characteristics of sample water prior to coagulation

\begin{tabular}{|c|c|c|c|c|}
\hline \multirow{2}{*}{ Sample } & \multicolumn{4}{|c|}{ Water Quality } \\
\cline { 2 - 5 } & $\mathrm{pH}$ & $\mathrm{TOC}(\mathrm{mg} / \mathrm{L})$ & $\mathrm{UV}_{254}\left(\mathrm{~cm}^{-1}\right)$ & $\mathrm{SUVA}(\mathrm{L} / \mathrm{mg}-\mathrm{m})$ \\
\hline Mixed Organic Compound 1 (MOC-1) & 8.25 & 5.39 & 0.174 & 3.23 \\
\hline Mixed Organic Compound 2 (MOC-2) & 8.45 & 6.66 & 0.240 & 3.60 \\
\hline
\end{tabular}

For artificial source water, MOC-2 has higher TOC and higher SUVA values than MOC-1 because MOC-2 was composed by greater SRHA concentration than MOC-1. Higher SUVA value indicated that NOM in all source water contains more hydrophobic organic fractions.

\section{Effect of coagulation on organic fractions removal}

The effect of coagulation on organic carbon fraction removal, as detected by OCD, was described in Fig. 2, which was given as an example. Figure 3 and Fig. 4 present the Peaks A-D area removal as resolved by peak-fitting from alum and
$\mathrm{FeCl}_{3}$ dosage, respectively. In addition, these figures describe the total area of treated water after coagulation and the percentage removal of area in each peak, as compared to the untreated water. Firstly, it can be seen that the increasing coagulant dosage could decrease all organic fractions, as shown in a decrease of all peaks.

Secondly, it indicates that humic substances, which are represented by Peak B, show a higher decreasing than all other peaks after treated by both coagulant. Humic substances present molecules with conjugated $\mathrm{C}=\mathrm{C}$ double bonds and consist of aromatic structure, and thus they are more hydrophobic, as shown in high SUVA value, than the non-humic substances. It has been well
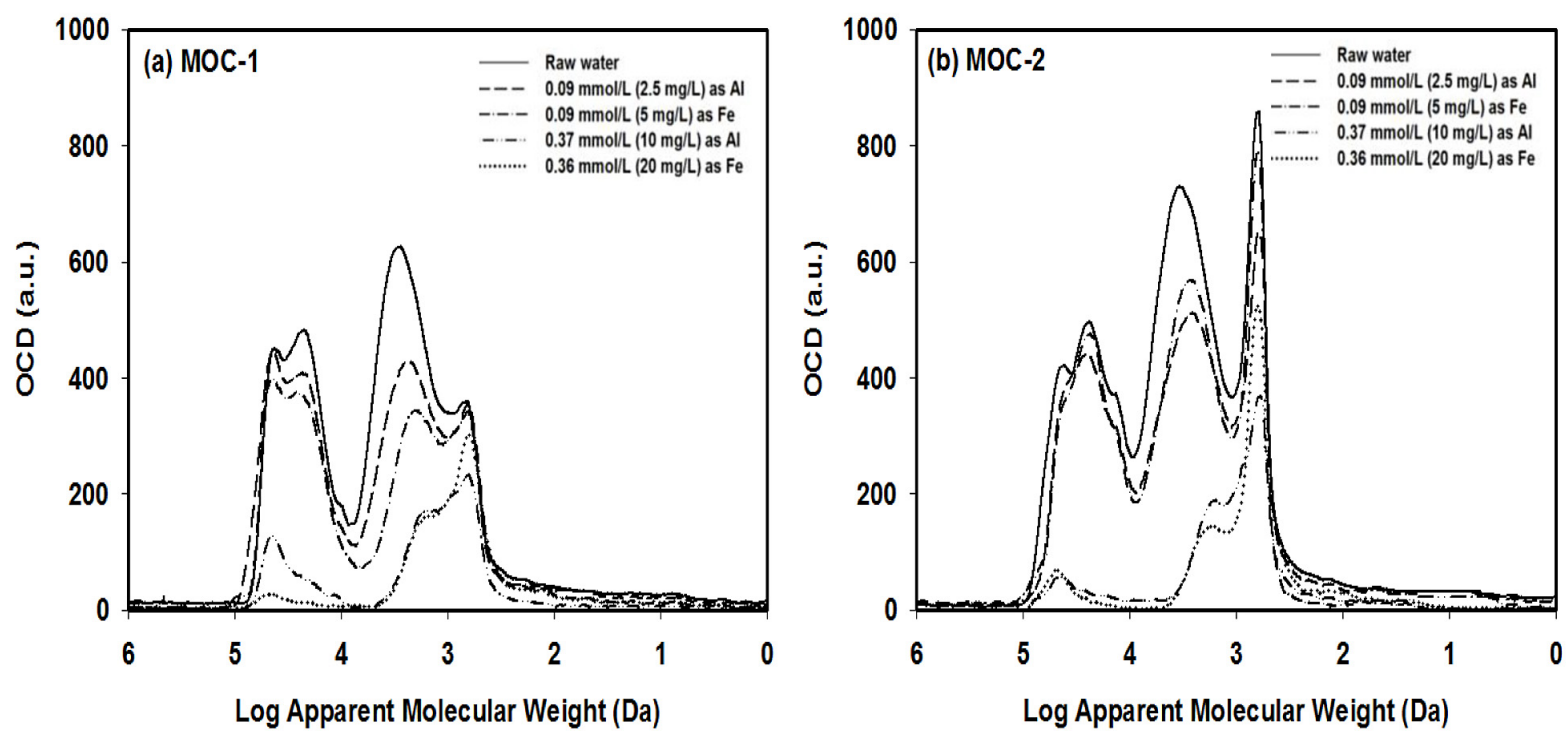

Fig. 2. Characteristic of organic fractions by HPSEC-OCD in source water and in treated water under various coagulant dosage (a) MOC-1, and (b) MOC-2 


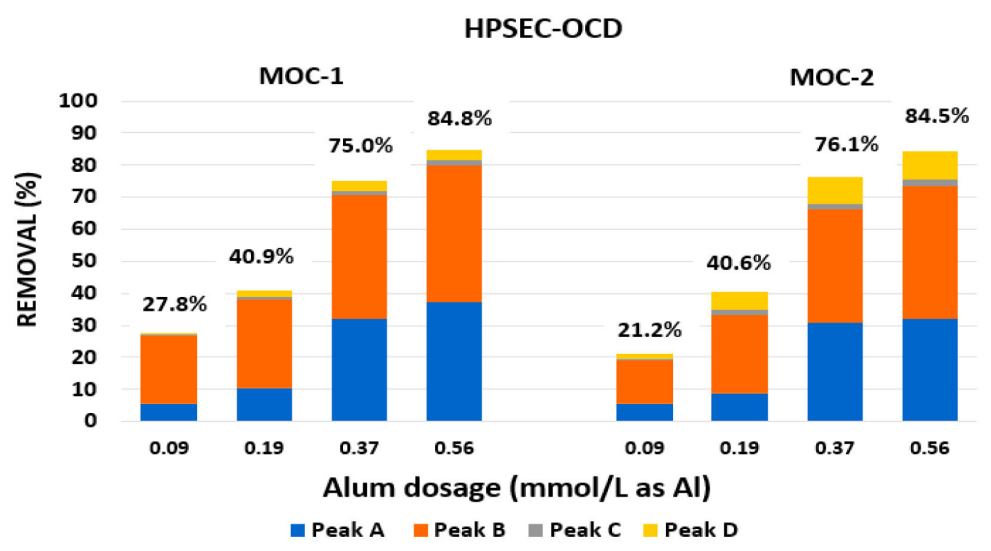

Fig. 3. The organic fraction removal in source water by alum coagulation under various dosages using HPSEC-OCD combined with peak-fitting.

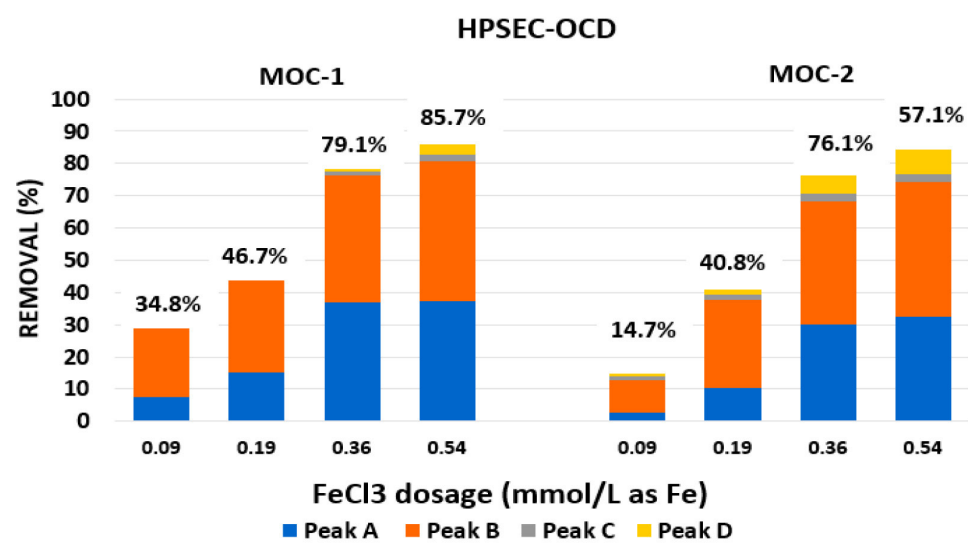

Fig. 4. The organic fraction removal in source water by $\mathrm{FeCl}_{3}$ coagulation under various dosages using HPSEC-OCD combined with peak-fitting

found in the previous studies that the humic substances are more amenable to removal by coagulation than the non-humic substances (Chow et al., 2009; Hidayah et al., 2016). Third, alum and $\mathrm{FeCl}_{3}$ resulted in a comparable percentage removal of Peak A, Peak B, and Peak C compared with removal of Peak $\mathrm{D}$, as shown in all data under the same coagulant dosage coagulant in $\mathrm{mmol} / \mathrm{L}$. Peak D showed a higher removal with alum than $\mathrm{FeCl}_{3}$. It indicated that those coagulants have different ability in removing low molecular weight organic fractions.

It also showed that in the different organic fractions, the greatest removal of specific peak occurred in Peak B. The reduction of Peak B by $\mathrm{FeCl}_{3}$ coagulant was about $43 \%$, and slightly higher removal than Peak A. The coagulation mechanism with alum or $\mathrm{FeCl}_{3}$ probably occurred by charge neutralization through positively charged hydrolyzed species forms at lower $\mathrm{pH}$ values $(\mathrm{pH}<6)$, while at higher $\mathrm{pH}(\mathrm{pH}>6)$ values, it probably occurred due to the adsorption of humic substances on the hydroxide precipitate (Dempsey et al., 1984; van Benschoten and Edzwald, 1990; Rigobello et al., 2011). Specific organic fraction removal could probably be described as complexation. The complexation by NOM hindered the hydrolysis of coagulant by occupying the growth sites: within the aggregates, hydrolysis product was present in the form of small oligomeric species, which exhibit a strong affinity toward aromatic compound (Ritter et al., 1999; Tubic et al., 2013). Low molecular weight fraction, such as Peak C and Peak D tend to be more hydrophilic and some of them present a negligible charge density; therefore, these fractions are considered difficult in obtaining high removal by coagulation (Hidayah et al., 2019).

Nevertheless, the removal of low molecular weight, especially removal of Peak D that is slightly higher than the removal of Peak C, is probably owing to predominant monomeric of 
alum species. Masion et al., (2000) found that the Al monomers were presented with small organic acids compounds, which was found as predominant species. In comparison with previous studies, this study, which used artificial water, a high removal of organic fraction was obtained than with river water (Hidayah et al., 2017; Cahyonugroho and Hidayah, 2018). It is probably indicated that the river water contains more complex organic fractions, which is categorized as recalcitrant matter, and less amenable to removal by coagulation. It was reported that the chemical and physical characteristics of organic matter, including the molecular weight, the solubility of organic compounds, the charge density of molecules, or the functional group composition, will determine the degree of organic fractions removal by coagulation (Chow et al., 2009; Han et al., 2015; Hidayah et al., 2016).

\section{Effect of coagulation on DBPs removal}

Figure 5 shows the percentage reduction of THMs formation potential (THMFP) and HAAs formation potential (HAAFP) between the source and treated water MOC-1 and MOC-2 from coagulation under various alum and $\mathrm{FeCl}_{3}$ dosages. Firstly, the results show that the increasing of both coagulant dosages could have increased the percentage reduction in both DBPs precursors. The characteristics of NOM, including carboxylic/phenolic acidity, aromatic/aliphatic, hydrophobic/hydrophilic content have been shown to affect the formation of DBPs (Liang and Singer, 2003; Bond et al., 2009; Kristiana et al., 2014). Therefore, according to Figure 2, all peaks decreased significantly with increasing coagulant dosage in the coagulation process, it corresponded to DBPFP decreased with increasing coagulant dosage.

Secondly, comparison of the DBPFP removal showed that the HAAFP removal lead to a greater reduction than the THMFP removal. It has been investigated that more HAAs precursors were removed than THMs precursors, because the former usually have higher hydrophobic carbon, and are relatively more amenable to the removal of organic fractions by coagulation (Hua and Reckhow, 2007; Liang and Singer, 2003; Reckhow and Singer, 2011). This is consistent with the higher SUVA value of all source water, as shown in Table 3. Coagulant speciation also have the greatest role in reduction of aliphatic structure with many negative charge, which is known as THM precursors, by charge neutralization at low $\mathrm{pH}(\mathrm{pH}<6)$ as well as HAA precursors with MW $<30 \mathrm{kDa}$ (Zhao et al., 2008).

Third, the figure shows that $\mathrm{FeCl}_{3}$ showed mostly higher removal than alum coagulant. The difference between the $\mathrm{FeCl}_{3}$ and alum reduction levels of DBPFP is attributed to a greater affinity of a fraction of NOM for ferric hydroxide floc, presents roughly two times more active positive charges than that for alum hydroxide (Uyak and Toroz, 2005). In addition, the $\mathrm{FeCl}_{3}$ coagulant shows a competition with alum in removing DBPs compound, including THMs and HAAs. The behavior of coagulants according to the DBPFP removal fluctuated constantly. Probably due to those coagulants, the species variation, with different ability to remove DBPs precursors, was generated during the coagulation process (Zhao et al., 2008).
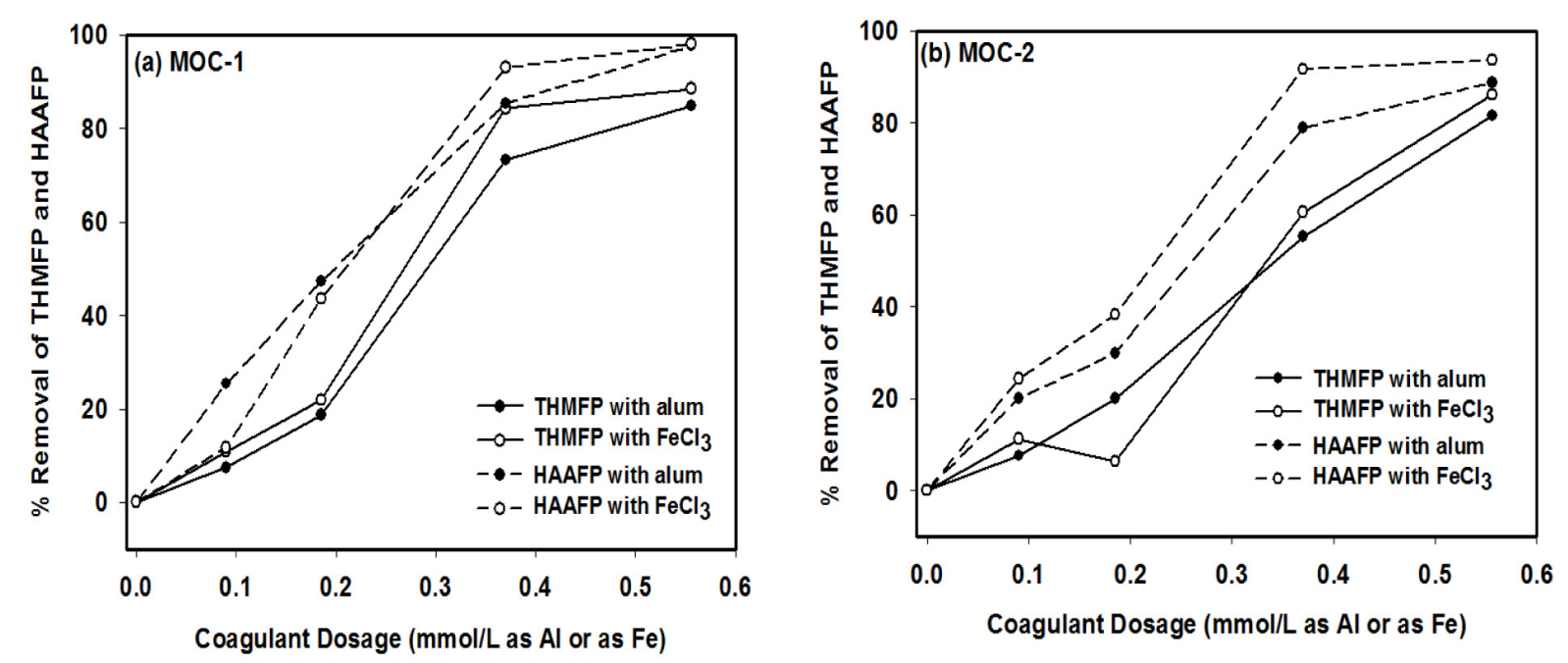

Fig. 5. Effect of coagulants on DBPFP removal in source water (a) MOC-1, and (b) MOC-2 


\section{CONCLUSIONS}

The conclusions of this study can be drawn according to the results; both alum and $\mathrm{FeCl}_{3}$ coagulant are amenable to a decrease in all organic fractions along with increasing coagulant dosage. Decreasing all organic fractions indicated a reduction of organic matter in water, and it showed a consistency with decreasing DBPFP in terms of THMFP and HAAFP. Alum and $\mathrm{FeCl}_{3}$ resulted in almost similar percentage removal of all peaks, except Peak D, which showed a higher removal of Peak D with alum than $\mathrm{FeCl}_{3}$. The HAAFP removal led to a greater reduction than the THMFP removal and $\mathrm{FeCl}_{3}$ showed higher removal than alum coagulant. It indicated that the coagulants have different ability in removing specific organic fractions and specific DBPs formation. Further study should be conducted to identify which THMFP or HAAFP species could be removed by coagulants.

\section{Acknowledgement}

Great appreciation for funding is given to Direktorat Jenderal Penguatan Riset dan Pengembangan, Kementerian Riset, Teknologi dan Pendidikan Tinggi, Republik Indonesia, under scheme Bantuan Seminar Luar Negeri 2019 with letter No. B/1359/E5.3/KI.03.01/2019.

\section{REFERENCES}

1. APHA, AWWA, WEF (2012) Standard Methods for the Examination of Water and Wastewaters. $21^{\text {th }}$ ed. American Public Health Association, Washington, D.C.

2. Bond T, Henriet O, Goslan EH, Parsons SA, Jefferson B (2009) Disinfection by-product formation behavior of natural organic matter surrogates. Environ Sci Technol 43, 5982-5989.

3. Cahyonugroho OH, Hidayah EN (2018) Characteristics of natural organic matter (NOM) surrogates under different disinfection. J Eng Applied Sci 13 (20), 8372-8376.

4. Chow CWK, van Leeuwen J, Fabris R, Drikas M (2009) Optimized coagulation using aluminium sulfate for the removal of dissolved organic carbon. Desalination 245 (1-3), 120-134.

5. Dempsey BA, Ganho RM, O’Melia CR (1984) Coagulation of humic substances by means of aluminum salts. J AWWA 76(4), 141-150.

6. Edzwald JK, Tobiason JE (2011) Chemical principles, source water composition, and watershed protection. In: Edzwald JK (ed) Water quality and treatment: a handbook on drinking water. AWWA McGraw-Hill, New York, pp. 76.

7. Han Q, Yan H, Zhang F, Xue N, Wang Y, Chu Y, Gao B (2015) Trihalomethanes (THMs) precursor fractions removal by coagulation and adsorption for bio-treated municipal wastewater: molecular weight, hydrophobicity/hydrophily and fluorescence. J Hazard Mater 297, 119-126.

8. Hidayah EN, Chou, YC, Yeh, HH (2016) Using HPSEC to identify NOM fraction removal and the correlation with disinfection by-product precursors. Water Sci Technol 16 (2), 305-313.

9. Hidayah EN, Chou YC, Yeh HH (2017) Comparison between HPSEC-OCD and F-EEMs for assessing DBPs formation in water. J Environ Sci Health Part A 52 (4), 391-402.

10. Hidayah EN, Yeh HH (2018) Effect of permanganate preoxidation to natural organic matter and disinfection by-products formation potential removal. Journal of Physics: Conference Series 953.

11. Hidayah EN, Kamal MF, Rizqa F, Hendianto MR (2019) Pretreatment comparison between peroxidation and prechlorination on the changing of natural organic matter. Nature Environ Poll Technol 18 (1), 163-166.

12. Hua G, Reckhow DA (2007) Characterization of disinfection byproduct precursors based on hydrophobicity and molecular size. Environ Sci Technol 41 (9): 3309-3315.

13. Kim H, Yu M (2005) Characterization of natural organic matter in conventional water treatment processes for selection of treatment processes focused on DBPs control. Water Res 39, 4779-4789.

14. Krasner SW, Weinberg HS, Richardson SD, Pastor SJ, Chinn RS, Michael JO, Gretchen DT, Alfred D (2006) Occurrence of a new generation of disinfection byproducts. Environ Sci Technol 40 (23), 7175-7185

15. Kristiana I, Tan J, McDonald S, Joll CA, Heitz A (2014) Characterization of the molecular weight and reactivity of natural organic matter in surface waters. In: Rosario-Ortiz FL (ed) Advances in the physicochemical characterization of organic matter. American Chemical Society, Washington DC, 209-233.

16. Lai CH, Chou YC, Yeh HH (2015) Assessing the interaction effects of coagulation pretreatment and membrane material on UF fouling control using HPSEC combined with peak-fitting. J Membrane Sci 474, 207-214.

17. Lamsal R, Montreuil KR, Kent FC, Walsh ME, Gagnon GA (2012) Characterization and removal of natural organic matter by an integrated membrane system. Desalination 303, 12-16. 
18. Leenher J, Croué JP (2003) Characterizing dissolved aquatic matter. Environ Sci Technol 37, 18A-26A.

19. Liang L, Singer PC (2003) Factors influencing the formation and relative distribution of haloacetic acids and trihalomethanes in drinking water. Environ Sci Technol 37 (13), 2920-2928.

20. Masion A, Ritter AV, Rose J, Stone WEE, Teppen BJ, Rybacki D, Bottero JY (2000) Coagulationflocculation of natural organic matter with $\mathrm{Al}$ salts: speciationn and structure of the aggregates. Environ Sci Technol 34, 3242-3246.

21. Matilainen A, Gjessing ET, Lahtinen T, Hed L, Bhatnagar A, Sillanpää M (2011) An overview of the methods used in the characterisation of natural organic matter (NOM) in relation to drinking water treatment. Chemosphere 83 (11), 1431-1442.

22. PeakFit (2003) Peak separation and analysis software: user manual. Seasolve Software, Inc.

23. Reckhow D, Singer PL (2011) Formation and control of disinfection by-products. In: Edzwald JK (ed) Water quality and treatment: a handbook on drinking water. AWWA McGraw-Hill, New York, pp. 59.

24. Rigobello ES, Dantas ADB, Benardo LD, Vieira EM (2011) Influence of the apparent molecular size of aquatic humic substances on colour removal by coagulation and filtration. Environ Technol 32(15), 1767-1777.

25. Ritter AV, Rose J, Masion A, Bottero JY, Laine JM (1999) Chemistry aand structure of aggregates formed with $\mathrm{Fe}$-salts and natural organic matter. Colloids Surf A: Physicochem Eng Asp 147, 297-308.

26. Sillanpää M, Matilainen A, Lahtinen T (2015) Characterization of NOM. In: Silaanpää M (ed) Natural organic matter in water: characterization and treatment method. Butterworth-Heinemann, Oxford, 17-53.

27. Singer PC (2006) DBPs in drinking water: additional scientific and policy considerations for public health protection. J AWWA 98 (10), 73-80.

28. Tran NH, Ngo HH, Urase T, Gin KYH (2015) A critical review on characterization strategies of organic matter for wastewater and water treatment processes. Bioresource Technology, 193, 523-533.

29. Tubic A, Agbaba J, Dalmacija B, Molnar J, Maletic S, Watson M, Perovic SU (2013) Insight into changed during coagulation in NOM reactivity for trihalomethanes and haloacetic acids formation. J Environ Manag 118, 153-160.

30. Uyak V, Toroz I (2005) Enhanced coagulation of disinfection by-products precursors in a main water supply of Istanbul. Environmental Technology 26, 261-266.

31. van Benschoten JE, Edzwald JK (1990) Chemical aspects of coagulation using aluminum salts-I. Hydrolytic reactions of alum and polyaluminum chloride. Water Res 24 (12), 1519-1526.

32. Wang DS, Zhao YM, Yan MQ, Chow CWK (2013) Removal of DBP precursors in micro-polluted source waters: A comparative study on the enhanced coagulation behaviour. Sep Purif Technol 118, 271-278.

33. Xie P, Chen Y, Ma J, Zhang X, Zou J, Wang Z (2016) A mini review of peroxidation to improve coagulation. Chemosphere 155, 550-563.

34. Zhao H, Hu CZ, Liu HJ, Zhao X, Qu JH (2008) Role of aluminium speciation in the removal of disinfection byproduct precursors by a coagulation process. Environ Sci Technol 42, 5752-5758. 